\title{
Callovian-Volgian dinocyst stratigraphy of the Central Trough in the Danish North Sea Area
}

\author{
NIELS E. POULSEN
}

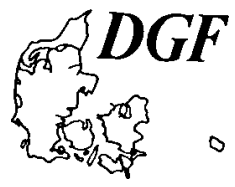

\begin{abstract}
Poulsen, N. E.: Callovian-Volgian dinocyst stratigraphy of the Central Trough in the Danish North Sea Area. Bull. geol. Soc. Denmark, vol. 35, pp. 1-10. Copenhagen, October, 29 th, 1986. https://doi.org/10.37570/bgsd-1986-35-01

The Danish North Sea wells U-1 and E-1 have been dated on the basis of dinocysts and correlated with the established ammonite stratigraphy of Western Europe. The palynostratigraphy of the $U=1$ well shows that the age of the Jurassic lithostratigraphic units is of Callovian to Kimmeridgian age. In the E 1 well, only the upper part of the Farsund Formation (of Jensen et al., 1986) has been penetrated. The age of this part is of Ryazanian to Volgian age. The four new formations (Lower Graben Sand Formation, Middle Graben Shale Formation, Lola Formation and Farsund Formation (of Jensen et al., 1986) show a marked difference in organic facies. It seems possible to relate these differences in organic facies to sea-level chan-ges.
\end{abstract}

Niels E. Poulsen, Geological Survey of Denmark, Thoravej 31, DK-2400 Copenhagen NV, Denmark, February 12th, 1985.

This report presents the result of palynological studies of two wells (U-1 and E-1) from the Central Trough area. The first part of the report gives the biostratigraphic dating of the samples. In the second part accumulation rates are estimated. They document great variation in the sedimentation history. Finally, a comparison of the palynofacies of the samples with the accumulation rate and eustatic sea-level changes is presented.

\section{Geographic scope, lithostratigraphy and subsidence}

The E-1 and U-1 wells are situated in the Danish part of the Central Trough area in the North Sea (fig. 1). The E-1 well is situated in the Tail End Graben and the U-1 well in the Southern Saltdome Province.

The Middle and Upper Jurassic sequences in the Central Trough area are divided into 6 new formations (Jensen et al., in prep.) (fig. 2). The equivalent lithostratigraphic units from the Norwegian North Sea and from England are also shown and correlated with these units in fig. 2 .

The lithostratigraphic nomenclature and description used in the text and in the figures are based on Jensen et al. (1986).
The Middle Jurassic sequence (the Lower Graben Sand and the Middle Graben Shale Formations) consists of deltaic or fluviatile coal-bearing sandstones, claystones and heteroliths. The Upper Jurassic sequence (the Lola Formations and the Farsund Formations) is a marine claystone. The Lola Formation unit is a grey, often silty, and slightly calcareous claystone. The Farsund Formations unit is a dark grey to brownish or olive black laminated, shaly, slightly silty claystone with dolomite stringers.

Near the marginal structural highs of the Central Trough are minor sand bodies. The sandy Upper Jurassic - Lower Cretaceous formation Poul Sand is located on the down faulted SW margin of the Ringkøbing-Fyn High. These units consist of grey sandstones with interbedded claystones and heteroliths. The sandy Upper Oxfordian - Lower Kimmeridgian formation Heno Sand is situated along the northeastern margin of the Dogger High. This formation consists of grey to white sandstones with minor conglomerates, siltstones, claystones and heteroliths.

The subsidence history of the Jurassic sequences is discribed in Hansen \& Mikkelsen (1982) and in Holm (1983). Both reports conclude that strong subsidence took place in Late Jurassic time. 


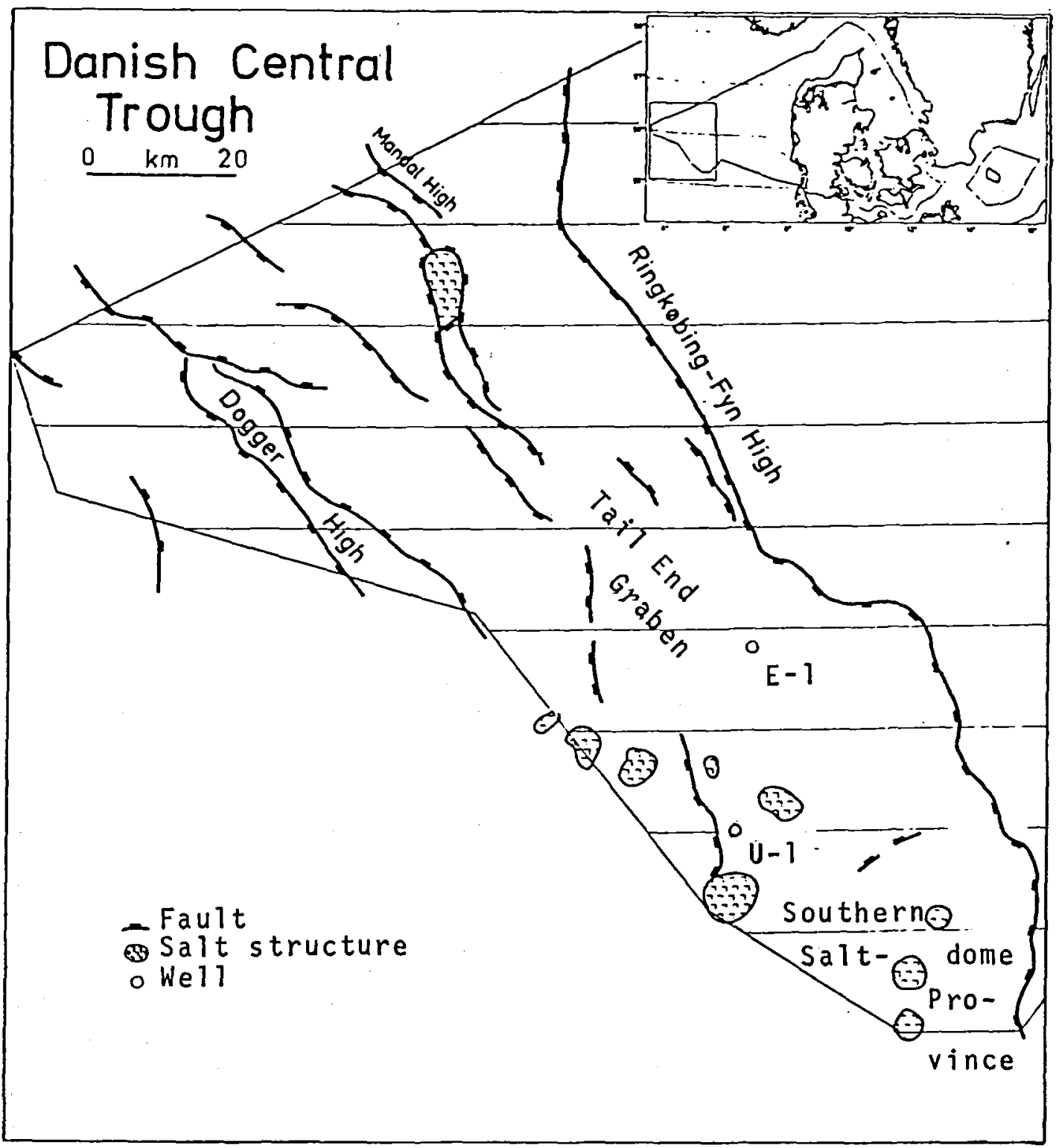

Fig. 1. Location map for the released wells E-1 and U-1.

\section{Biostratigraphy}

Methods

The dinocysts occurring in the Danish North Sea wells in most cases are correlated to the English dinocyst stratigraphy (Raynaud, 1978; Riley \& Fenton, 1982; Sarjeant, 1979; Woollam \&
Riding, 1983) which again has been correlated to the classic subboreal ammonite stratigraphy.

In this work, cutting samples as well as sidewall cores have been dated. Each cutting sample (C.S.) has been dated to the oldest range top of the species found in the sample. The age of a cutting sample is therefore a minimum age.

In the first feet of the drilled section below a 


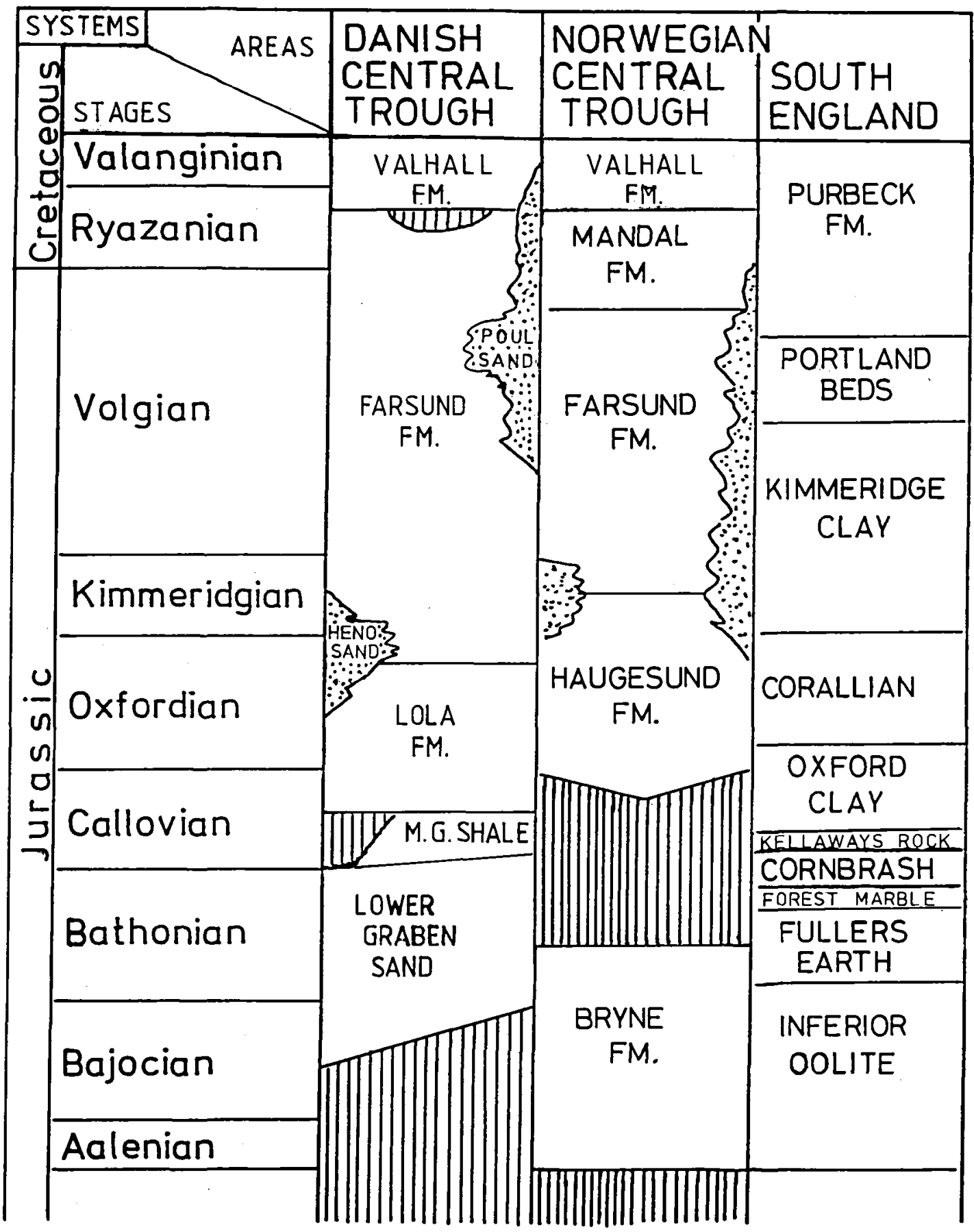

Fig. 2. Lithostratigraphic subdevision of the Central Trough: Danish Sector (after Jensen et al., 1986 (see this paper for further revisions)) and Norwegian Sector (after Vollset \& Dore, 1984), and a generalized South English composite section (after Sarjeant, 1979). (M. G. Shale = Middle Graben Shale Formation). 
casing shoe, species originating from cavings cannot be expected. The age of the first cutting sample below a casing is regarded as exact age.

Each side wall core sample (S.W.C.) has been dated to the period in which all the species have a concurrent range (contemporary occurrence). The age of a side wall core is therefore also regarded as exact age.

Using this method, the age of cutting samples from the $U-1$ well is in agreement with the age found from the side wall core samples from the Late Callovian to Middle Oxfordian. On the other hand, the minimum age of the cutting samples from the Farsund Formation in the U-1 well is less than the ages based on the side wall core samples. The cause of this discrepancy seems to be due to the low diversity and density in these cutting samples. (These cutting samples are omitted in fig. 7).

\section{Results}

\section{Well E-1}

Fig. 3 shows the previously reported top occurrence of the species used for the stratigraphic in-

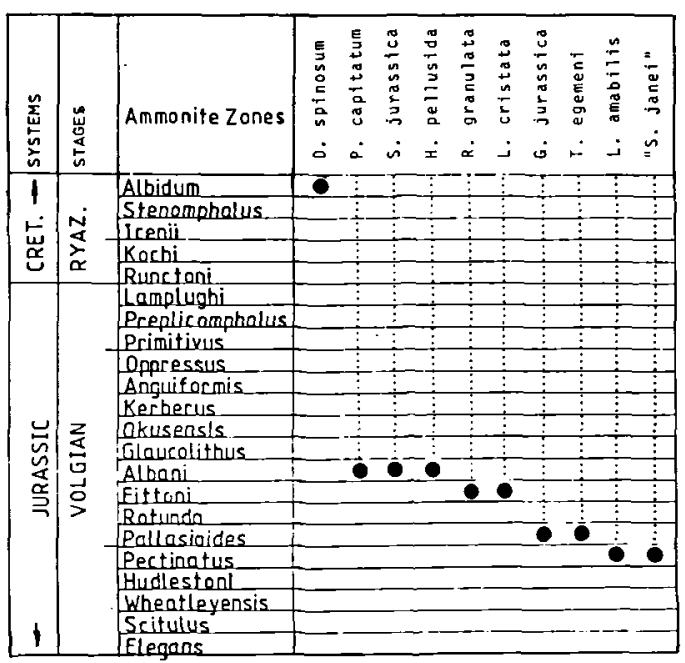

Fig. 3. The known top occurrence (last occurrence or first downhole occurrence) (after Davey, 1982; Piasecki, 1980; Raynaud, 1978; Sarjeant, 1979; Woollam \& Riding, 1983) of the dinocyst species of the E-1 well cutting samples of the Farsund Formation used for dating of the samples. For the stratigraphic correlation of the samples see fig. 7. ("Senoniasphaera janei" is an unpublished species of Piasecki, 1980).

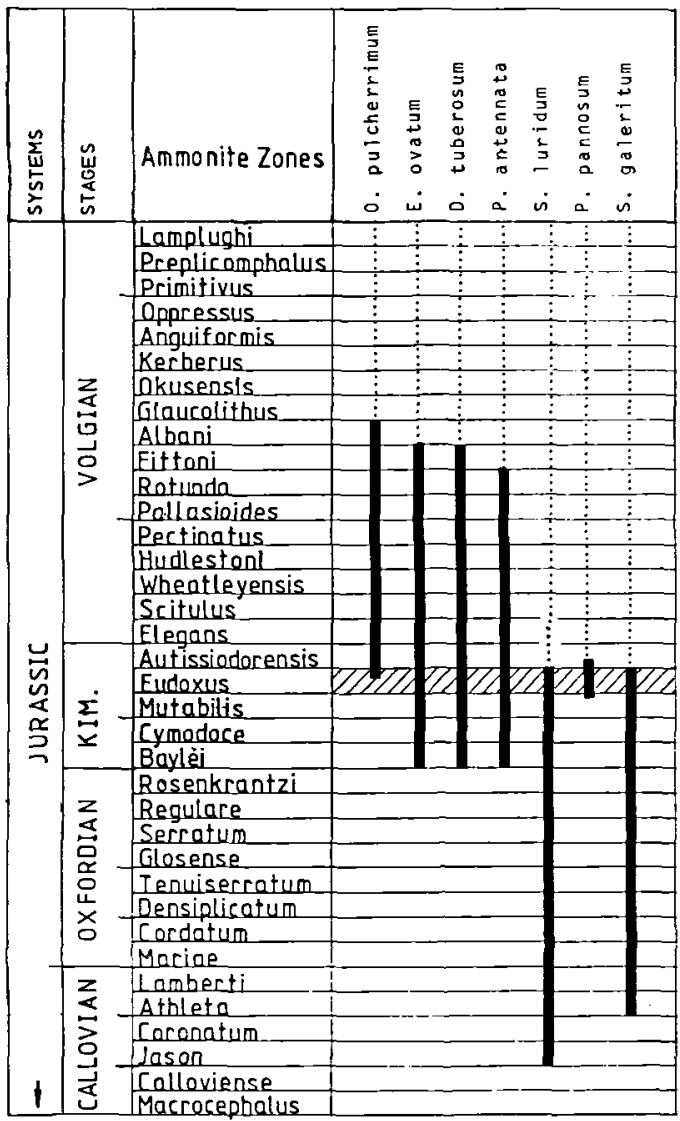

Fig. 4. The known stratigraphic range (after Raynaud, 1978; Riley \& Fenton, 1982; Sarjeant, 1979; Woollam \& Riding, 1983) of the dinocyst species of the U-1 well side wall core sample 8215' used for the dating of the sample. For the stratigraphic correlation of the sample see fig. 7 .

terpretation of the well. In all samples, diverse dinocyst assemblages are found to indicate a Middle to Early Volgian age. (See fig. 7 concerning the dating of the samples).

\section{Well U-1}

Fig. 4 shows the previously reported ranges of the stratigraphic marker species from the uppermost side wall core of the Farsund Formation in the well. The age of this sample is Upper Kimmeridgian, equivalent to the Eudoxus ammonite Zone.

Occisucysta monoheuriskos is found in the cutting sample at $9280^{\prime}$. This species is reported only from the Cymodoce ammonite Zone, indicating a minimum age of Early Kimmeridgian. At $9550^{\prime}$ 


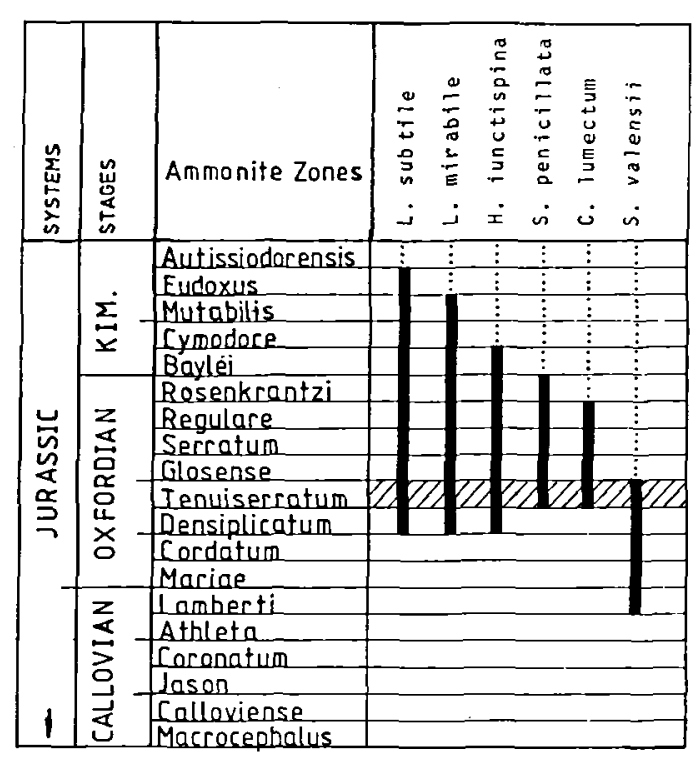

Fig. 5. The known stratigraphic range (after Raynaud, 1978; Riley \& Fenton, 1982; Sarjeant, 1979; Woollam \& Riding, 1983) of dinocyst species of the $U-1$ well cutting sample $10060^{\prime}$ $+10120^{\prime}$ used for dating of this sample. This cutting sample is the first sample below the casing shoe at $9985^{\prime}$. For the stratigraphic correlation see fig. 7 .

the first downhole occurrence of Systematophora penicillata indicates strata of Oxfordian age.

In Fig. 5 the reported ranges of the stratigraphic marker species of the cutting sample $10060^{\prime}+10120^{\prime}$ from the U-1 well are shown. This was the first sample taken below the casing show at $9985^{\prime}$. The dinocyst assemblage of this sample is characteristic of the Middle Oxfordian. The concurrent range of the species found in this samples clearly indicates equivalence to the Tenuiserratum ammonite Zone.

In the cutting sample $10430^{\prime}$, species of the "Meiourogonyaulax caytonensis group" indicates an Early Oxfordian age. In this sample, Gonyaulacysta jurassica "hlanc" was also found indicating a mid-Early Oxfordian minimum age.

G. jurassica "hlanc" is a new subspecies of $G$. jurassica (Poulsen, 1986). Its stratigraphic range seems to be very short and equivalent to the Praecordatum ammonite Subzone (the upper subzone of the Mariae ammonite Zone) and the lowermost part of the Cordatum ammonite Zone (Poulsen, 1986).

In the side wall core sample 10474', Leptodinium eumorphum is found, indicating a late
Early Oxfordian or younger age, equivalent to the Cordatum ammonite Zone.

In the cutting sample $10570^{\prime}+10670^{\prime}$ and in the side wall core sample $10654^{\prime}$, Mendicodinium groenlandicum is very common. This species is common in Lower Oxfordian strata and very common in Upper Callovian strata. According to this, the age is assumed to be Late Callovian.

Below this level, only few dinocysts were found. At 10800' some badly preserved Ctenidodinium specimens were found. Pareodinia prolongata occurs at $10970^{\prime}$, indicating a Callovian or older age. The comtemporary occurrence (concurrent range) of Pareodinia prolongata and Rigaudella filamentosa, (Hoelstad, 1986) in the sidewall core samples from 10940' to $10990^{\prime}$, indicates a Callovian age for this level (fig. 6). This is supported by the presence of Gonylaulacysta jurassica, which is uncommon below the Callovian (Raynaud, 1978; Sarjeant, 1979; Woollam \& Riding, 1983). (See fig. 7 concerning the dating of the samples).

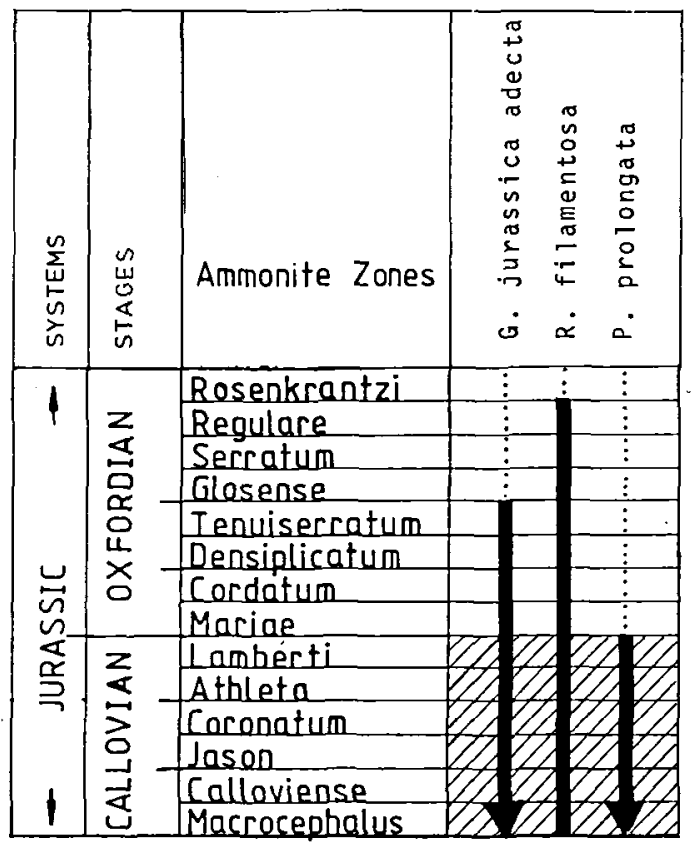

Fig. 6. The known stratigraphic range (after Raynaud, 1978; Riley \& Fenton, 1982; Sarjeant, 1979; Woollam \& Riding, 1983) of the dinocysts of the U-1 well used for stratigraphic dating of the side wall cores $10940^{\prime}-10990^{\prime}$. For the stratigraphic correlation of these samples see fig. 7 . 


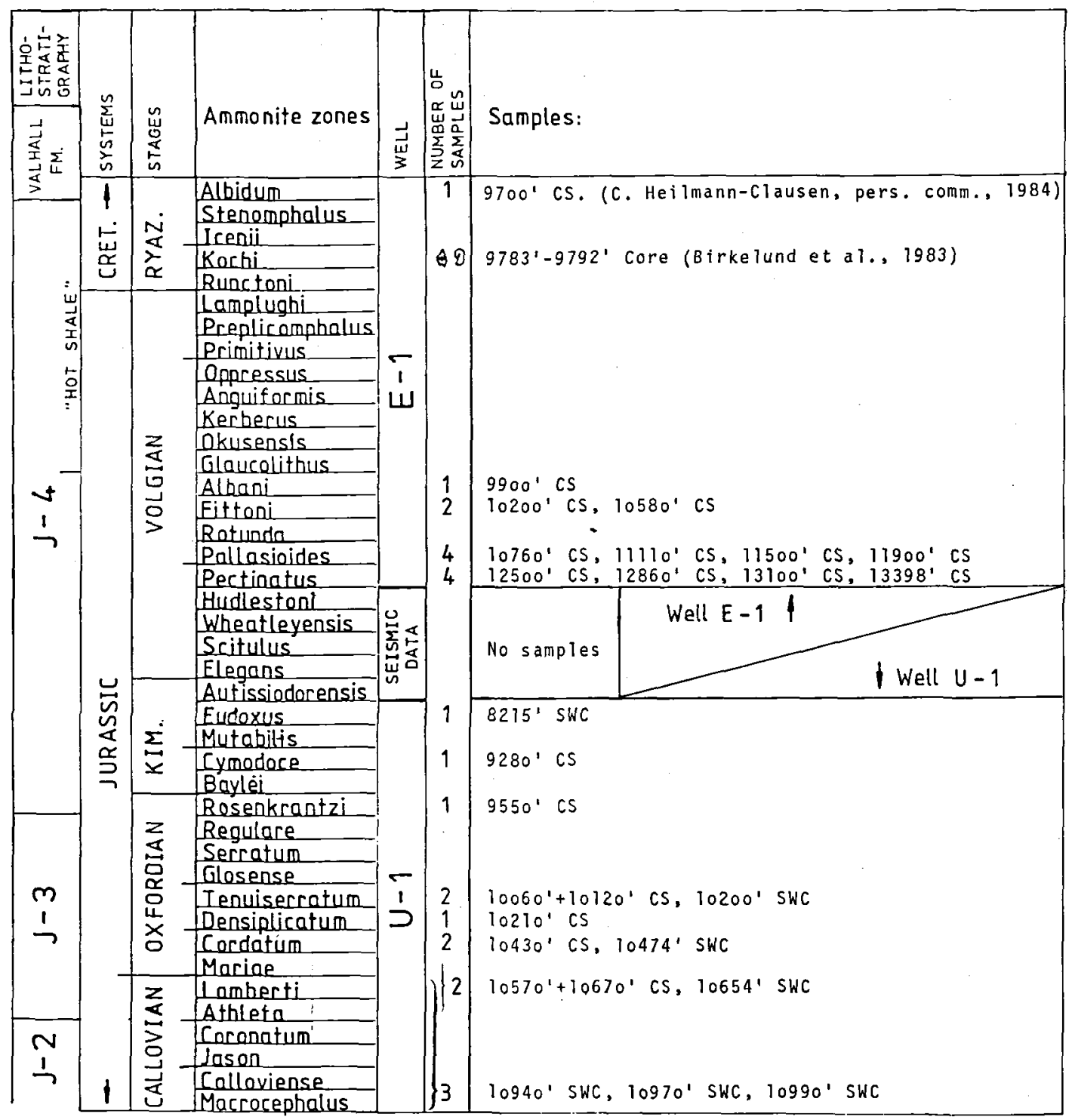

Fig. 7. Summary of the biostratigraphic correlation and position of samples. Total depth of the E-1 well is $13398^{\prime}$, total depth of the $\mathrm{U}-1$ is $16045^{\prime}$.

The upper boundary of the Farsund Formation

Dingodinium spinosum is present in the lowermost part of the Valhall Formation in the E- -1 well, indicating that the base of this formation is of Ryazanian age (Heilmann-Clausen, pers. comm., 1984). This contrasts with the dating by Birkelund et al. (1983), who indicated a Valanginian age for the boundary between the Farsund Formation unit and the overlying Valhall Formation.
On the basis of ammonites and dinocysts, a core (9783'-9792') from near the top of the Farsund Formation unit in the E-1 well was correlated to the Cannosphaeropsis thula dinocyst Subzone and to the Kochi ammonite Zone (Lower Ryazanian) by Birkelund et al. (1983). These age determinations of the E-1 well does not support the theory of a "Late Cimmerian regional unconformity" between the new Farsund Formation and the Valhall Formation (See Birke- 
lund et al. (1983 p. 67) for discussion of this event).

In the $\mathrm{U}-1$ well in contrast, a major hiatus is present. This hiatus is however supposed to have been caused by salttectonic movements (See Michelsen (ed.), 1982).

\section{Summary of stratigraphy}

The Farsund Formation in the E-1 well is of Early Volgian to Ryazanian age. (Note, that the Farsund Formation has not been completely penetrated in this well). In the U-1 well the Farsund Formation is of latest Oxfordian to Kimmeridgian age. The Lola Formation is of Late Callovian or of Early Oxfordian age to Late Oxfordian age. The Lower Graben Sand Formation and the Middle Graben Shale Formation is of Callovian age in this well.

\section{Sedimentary history}

Most of the samples of the Farsund Formation in the E-1 well are of almost the same age. This indicates a very high accummulation rate as shown in fig. 8 , where the sediment thickness per ammonite zone is illustrated.

The accumulation rates of the Farsund Formation in the $\mathrm{U}-1$ well show much greater variation as compared to the Lola Formation. Owing to fewer and less accurate datings of the Middle Graben Shale and the Lower Graben Sand Formations, this level is illustrated with an apparently uniform accumulation rate.

The uppermost part of the Farsund Formation is informally known as the "hot shale". It is a shale rich in organic matter with high gamma ray readings. The "hot shale" appears to have been deposited in the Ryazanian after a period of strong subsidence in the Volgian. The "hot shale" appears to be a condensed sequence with a very low accumulation rate approximately $7 \mathrm{~mm} / 1000$ years (uncorrected for compaction and based on the assumption that each ammonite zone is equivalent to approximately 500.000 years). In contrast, the accumulation rate of the Pallasioides ammonite Zone reached $1000 \mathrm{~mm} / 1000$ years.

The condensed sequence does not appear to represent pronounced periods of non-sedimenta- tion, since caved specimens of Perrisseiasphaeridium insolitum occur in the investigated samples. The range of $P$. insolitum is restricted to the Kerberus to Lamplughi ammonite Zones. Consequently, the calculated accumulation rates may represent the actual sedimentation rates as well.

On the basis of seismic profiles through the E-1 well and the $U-1$ well it has been estimated that the sequence in other parts of the area which is not represented by the two wells comprises less than 200' (J. J. Møller, pers. comm., 1984). Consequently, this sequence, belonging in the uppermost Kimmeridgian and most of the Lower Volgian, appears to be another condensed sequence.

\section{Organic facies in relation to sea-level changes}

The accummulation rate of the Upper Jurassic seems to be dependent of local subsidence history and independent of the changes in sea level (fig. 8). In contrast to this, the organic facies reflect correlation to rising or falling sea level, as it will be explained below.

The organic facies are described in two ways: 1) The amount of structured organic material is estimated visually in relation to the amount of amorphous matter (fig. 8). 2) The organic material is classified according to Habib's (1979) three organic facies: exinitic facies, characterized by numerous spores and pollen and structured palynodebris such as vascular plant cuticle and tracheids; micrinitic facies, characterized by abundant amorphous palynodebris in the form of small dark particles and a palynoflora dominated by bisaccates and dinocysts; and xenomorphic facies, characterized by a palynoflora similar to that of the micrinitic facies, but distinguished by abundance of amorphous palynodebris composed of optically translucent particles.

The Middle and Upper Jurassic Formations seem to be easily distinguished on the basis of organic facies. The Lower Graben Sand and the Middle Graben Shale Formations is dominated by structured material of the exinitic organic facies. The Lola Formation is still of the exinitic organic facies, the amount of amorphous matter is larger, although it is not dominating. The lower part of the Farsund Formation is characterized by 


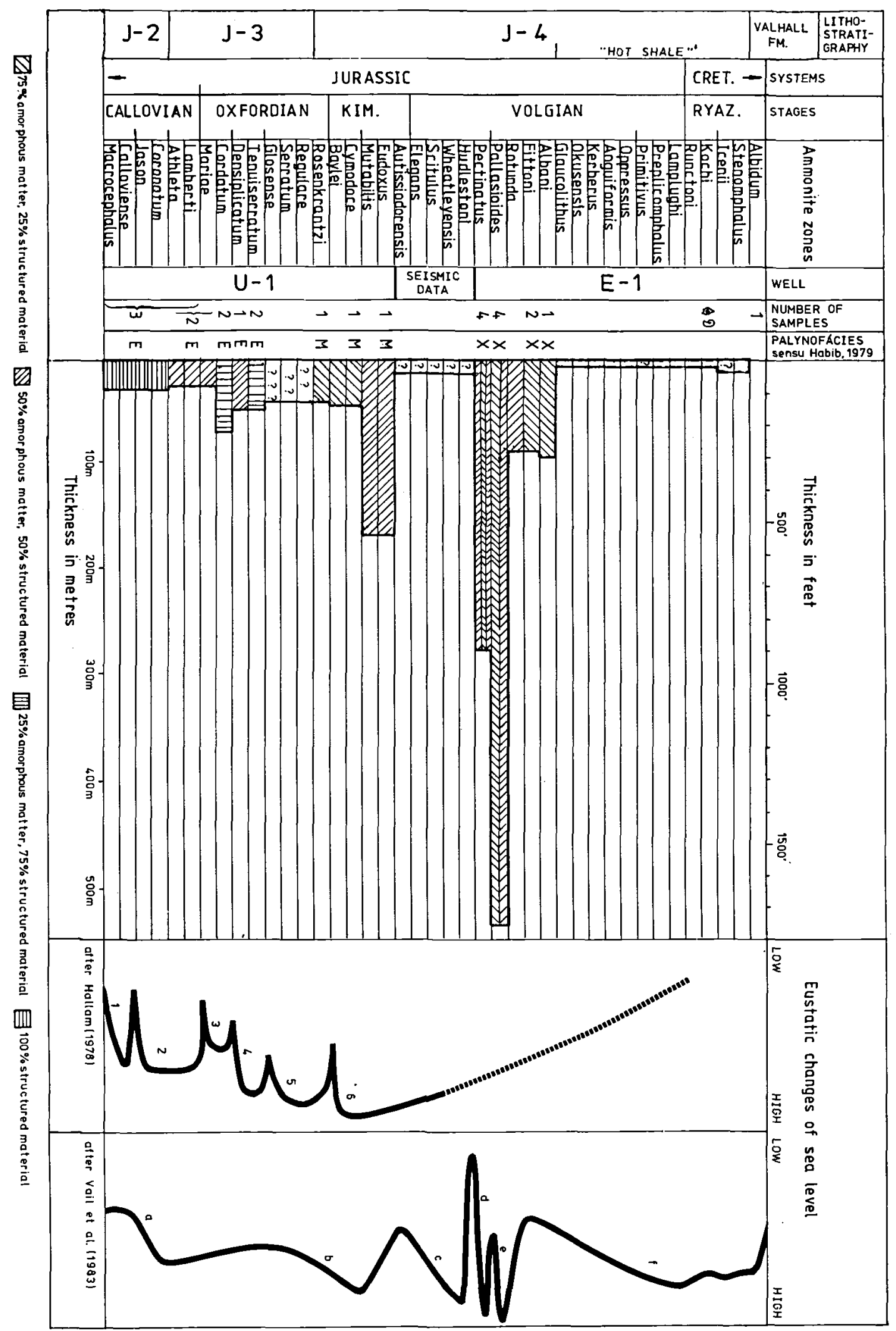


micrinitic organic facies and in the upper part of xenomorphic organic facies with dominance of optically translucent amorphous matter.

The regressive periods shown by the curves of Hallam (1978) and Vail et al. (1983) in fig. 8 correspond to higher content of structured material, whereas at least the longer transgressive periods correspond to a higher content of amorphous matter.

Hallam's data are based especially on interpretations of the strata in England. On this interpretations he correlated the changes in sea level to the chronostratigraphy.

Besides Vail's et al.'s sea-level changes, which are based on global unconformities interpretated from seismic reflictions, are shown in fig. 8. These sea-level changes are not as precisely correlated to the chronostratigraphy as Hallam's.

Each of the eustastic sea-level rise-fall cycles (fig. 8) has been numbered. The Middle Graben Shale Formation and the Lower Graben Sand Formation of the U-1 well has not been correlated to the ammonite stratigraphy, so this unit has not been compared to the curves of sea-level changes. As can be seen in fig. 8 , the end of sealevel cycles 3 and 4 are marked by a relatively higher content of structured organic material in the samples. Apparently the strata corresponding to the end of cycle 2 and 5 do not have a higher content of stuctured material.

During cycle 5 there is a shift from exinitic organic facies to micrinitic organic facies. According to Habib (1979) the organic material from the exinitic organic facies is contributed from prograding deltas, whereas the material of the micrinitic organic facies represents diminished sedimentation of terrigenous material; organic material of this facies was deposited by marine currents which sorted the organic material. This changes indicates a diminished terrigenous supply which can be explained in several ways. There could have been a geographic shift in the position of the delta, but if the organic content of the Upper Oxfordian - Lower Kimmeridgian strata is compared with the sea-level curve of Vail et al. (fig. 8) the sea-level rise here called b could explain the higher content of amorphous matter, and the micrinitic organic facies could then be explained by a sea-level rise, which would cause diminished deltaic supply and more dominating marine currents.

Hallam (1978) writes that the sea-level probably began to fall during the Volgian. Vail et al. (1983) showed, that there is a maximum sea-level rise in late Jurassic times corresponding to the Kimmeridgian and Volgian stages. They have found several changes in sea-level (fig. 8) but these changes cannot be correlated to the chronostratigraphy as precisely sa the changes presented by Hallam (1978). The maximum sealevel rise af Vail et al. (1983) seems to be equivalent to the deposition of strata with an organic content dominated by amorphous matter of Habib's (1979) xenomorphic organic facies. According to Habib the organic material of the xenomorphic organic facies is deposited from the sea without any influence of marine current activity.

Acknowledgments. This study is a part of an energy research project (EFP 1983). I. M. Jensen (Geological Survey of Denmark) typed the manuscript. T. Birkelund (University of Copenhagen), R. Bromley (University of Copenhagen), J. M. Hansen (Geological Survey of Denmark), S. Piasecki (Geological Survey of Greenland), L. B. Rasmussen (Geological Survey of Denmark) critically reviewed the manuscript.

\section{Dansk sammendrag}

Farsund Formationen (Jensen et al., 1986) i E-1 boringen (ned til slutdybden $i$ boringen (T.D.) 13.398 ) er blevet dateret ved hjælp af dinocyster. Alderen af hovedparten af lagserien er yngste del af aldre Volgien og aldste del af mellem Volgien. Den øverste del af formationen, der er en kondenseret lagserie, dækker aldersmæssigt tidsafsnittet mellem og yngre Volgien og Ryazanien.

I U-1 boringen er Lower Graben Sand, Middle Graben Shale, Lola og Farsund Formationerne (Jensen et al., 1986) blevet dateret. Lower Graben Sand og Middle Graben Shale Formationerne er således af Callovien alder, Lola Formationen af yngre Callovien til Oxfordien alder. Farsund Formationen dakker $\mathrm{i}$ denne boring kun øverste Oxfordien og Kimmeridgien.

De fire formationer viser en markant forskel i organisk facies (palynofacies). Det synes muligt at vise en sammenhæng mellem havniveau-svingninger og andringer $i$ organisk facies. Således markerer transgressionsperioder sig med dominans af ustruktureret (amorft) organisk stof, mens regressive perioder domineres af struktureret organisk materiale.

Fig. 8. Accumulation rate illustrated as thickness of sediments per ammonite zone. The distribution of structured and amorphous organic material is illustrated together with the sedimentation rate, and the organic facies is described according to Habib (1979). E = exinitic facies, $M=$ micrinitic facies and $X=$ xenomorphic facies. The eustatic sea-level curves of Hallam (1978) and Vail et al. (1983) are put in relation to the stratigraphy of the two wells. 


\section{References}

Birkelund, T., Clausen, C. K., Hansen, H. N. and Holm, L., 1983: The Hectoroceras kochi Zone (Ryazanian) in the North Sea Central Graben and remarks on the Late Cimmerian Uncomformity. Danmarks Geologiske Undersøgelse, Arbog 1982: 53-72.

Davey, R. J., 1982: Dinocyst stratigraphy of the latest Jurassic to Early Cretaceous of the Haldager No. 1 borehole, Denmark. Geological Survey of Denmark. Series B, 6: $58 \mathrm{pp}$.

Habib, D., 1979: Sedimentology of palynomorphs and palynodebris in Cretaceous carbonaceous facies south of Vigo Seamount. Initial Reports of the Deep Sea Drilling Project, 47(2): 451-465.

Hallam, A., 1978: Eustatic cycles in the Jurassic. Palaeogeography, Palaeoclimatology, Palaeoecology, 23: 1-32.

Hansen, J. M. and Mikkelsen, N., 1983: Hydrocarbon geological aspects of subsidence curves: interpretations based on realeased wells in the Danish Central Graben. Bulletin of the Geological Society of Denmark, 31(3-4): 159-169.

Hoelstad, T., 1986: Palynology of the Middle Jurassic Lower Graben Sand of the U-1 well, Danish Central Trough. Danmarks Geologiske Undersøgelse, Serie C. (in prep.)

Holm, L., 1983: Subsidence history of the Jurassic sequence in the Danish Central Graben. Danmarks Geologiske Undersøgelse, Arrbog 1982: 39-51.

Jensen, T. F., Holm, L., Frandsen, N \& Michelsen, O., 1986: Jurassic-Lower Cretaceous lithostratigraphic nomenclature for the Danish Central Trough. - Danmarks geologiske Undersøgelse, Serie A. (in prep.).

Michelsen, O. (editor), 1982: Geology of the Danish Central Graben. Geological Survey of Denmark. Series B, no. 8, 135 pp.
Piasecki, S., 1980: Middle to Late Jurassic dinoflagellate stratigraphy from Milne Land and Jameson Land (East Greenland) correlated with ammonite stratigraphy. Unpublished Ph.D. thesis, University of Copenhagen.

Poulsen, N. E., 1986: Callovian (Jurassic) to Ryazanian (Cretaceous) dinoflagellate biostratigraphy of the Danish Central Trough. Danmarks geologiske Undersøgelse, Serie A. (in prep.).

Raynaud, J. F, 1978: Principaux dinoflagelles caracteristiques du Jurassique Superieur D'europa du Nord. Palinologia, numero extraordinaire 1: 387-405.

Riley, L. A. \& Fenton, J. P. G., 1982: A dinocyst zonation for the Callovian to Middle Oxfordian succession (Jurassic) of North-West Europa. Palynology 6: 193-202.

Sarjeant, W. A. S., 1979: Middle and Upper Jurassic dinoflagellate cysts: The world excluding North America. American Association of Stratigraphic Palynologists Contributions Series 5B: 133-157.

Sarjeant, W. A. S., 1982: The dinoflagellate cysts of the Gonyaulacysta group: A Morphological and taxonomic restudy. American Association of Stratigraphic Palynologists, Contributions Series 9, 81 pp.

Vail, P. R., Hardenbol, J. and Todd, R. G., 1983: Jurassic uncomformities, chronostratigraphy and sea-level changes from seismic stratigraphy and biostratigraphy. Preprint from American Association of Petroleum Geologists, Memoir (in press).

Vollset, J. and Dore, A. G., (editors), 1984: A revised Triassic and Jurassic lithostratigraphic momenclature for the Norwegian North Sea. NPD-Bulletin 3: 53 pp.

Woollam, R. \& Riding, J. P., 1983: Dinoflagellate cyst zonation of the English Jurassic. Institute of Geological Sciences Report 83/2: 44 pp. 